Magdalena ŚWigost

ANNA DĄBROWSKA

Uniwersytet Jagielloński

w Krakowie

\title{
WŁAŚCIWOŚCI STYGMATU \\ A SYTUACJA ŻYCIOWA CZŁOWIEKA ZAGROŻONEGO STYGMATYZACJĄ
}

AвSTRAct. Świgost Magdalena, Dąbrowska Anna, Właściwości stygmatu a sytuacja życiowa człowieka zagrożonego stygmatyzacja [The Properties of Stigma and the Situation of Human Life]. Studia Edukacyjne nr 45, 2017, Poznań 2017, pp. 329-345. Adam Mickiewicz University Press. ISSN 1233-6688. DOI: $10.14746 /$ se.2017.45.22

It is stated that the properties of stigma have the key role in perceiving social relations and own life situation by the person who is in danger of the process of social stigma. It is ccognitively interesting how agreeing to the process of social stigma is shown in terms of difficulty that is being activated by specific feature, pressing, in exceptional sense, on seeing and controling the stigma.

This article contains the theoretical analysis of the process of social stigma in relation to its chosen features. There has been done an attempt to present mutual assorted interaction with the influence of blocking predicators or those restoring the process of social self-indicating and indicating

Key words: stigma, assorted interaction, properties of stigma, self-indication, indicating

\section{Wstęp}

Celem artykułu jest zaprezentowanie właściwości stygmatu w kontekście sytuacji życiowej człowieka zagrożonego stygmatyzacją. W sytuacji, w której spotykamy obcego człowieka, informacje o tym jaki on jest, jak wygląda, jakie reprezentuje poglądy, do jakiej należy grupy społecznej są dla nas pożyteczne o tyle, o ile potrafimy z nich wyciągnąć wnioski co do ewentualnych korzyści lub strat, jakie możemy ponieść $\mathrm{w}$ kontakcie $\mathrm{z}$ nim$^{1}$. Do kluczowych informacji w tym zakresie należą więc te, bezpośrednio związane z cechami posiada-

${ }^{1}$ J. Czapiński, Przesłanki ustosunkowań wobec innych ludzi, [w:] Psychologia spostrzegania społecznego, red. W.M. Lewicka, Warszawa 1985, s. 114. 
nego piętna dostrzeganego w kontakcie interpersonalnym. Dlatego, w niniejszym artykule zostanie przedstawiony moment spotkania osoby piętnowanej z piętnującą, z uwzględnieniem aspektu właściwości stygmatów. Podjęto próbę ukazania wpływu widoczności piętna oraz jego kontrolowalności na sposób postrzegania osoby doświadczającej skutków posiadanej cechy oraz strategie radzenia sobie $\mathrm{z}$ kłopotliwymi momentami powstałymi w relacjach mieszanych².

\section{Wyjaśnienie terminologiczne}

Rozpoczynając prezentację kluczowych kwestii, warto zwrócić uwagę na wyjaśnienie najważniejszego terminu, wokół którego zorganizowany jest proces stygmatyzacji, a więc na pojęcie stygmatu społecznego. E. Goffman ${ }^{3}$, twórca tego terminu, definiuje go jako: „cechę lub znamię, które naznacza nosiciela jako człowieka «okaleczonego» i wartego mniej niż «normalni» ludzie". Natomiast, stygmatyzacja jest to proces, który obejmuje reakcję społeczną na posiadane przez podmiot postrzegany właściwości stygmatyzujące oraz konstruowanie tożsamości stygmatyzowanego wokół jego piętna ${ }^{4}$.

Należy jednak już na początku zauważyć, że aby jakąś cechę można było określić jako stygmatyzująca, musi być ona zgodnie uznana za piętno. Przyjmuje się, że musi ona "psuć" interakcje nie tylko na poziomie indywidualnym, ale także grupowym. Atrybut nigdy nie jest piętnujący sam w sobie. Należałoby jednak zadać sobie pytanie, kto powinien podzielać opinię o piętnującym charakterze danej cechy. Odpowiedź jest bardzo złożona, ponieważ oceny te mogą być dokonywane w szerokim kontekście społecznym (np. w ramach konkretnej epoki historycznej), w ramach krótkotrwałego kontaktu dwóch osób lub też na dowolnym, innym poziomie pośrednim, jednak zawsze uznanie jakiejś cechy za piętnującą dokonuje się w odniesieniu do szerszej perspektywy społecznej.

Proces stygmatyzacji oraz przyjmowania negatywnych konotacji związanych z przypisywanymi etykietami jest bardzo złożony. Nie można jednoznacznie określić, że w stosunku do konkretnej osoby posiadającej cechy powszechnie uznane za piętnujące rozwiną się procesy właściwe dla stygmatyzacji społecznej, czy dla samostygmatyzacji, ponieważ stanowią

2 J.F. Davidio, B. Major, J. Crocer, Piętno: wprowadzenie i zarys ogólny, [w:] Społeczna psychologia piętna, red. T. Heatherton, R. Kleck, M. Hebl, J. Hull, Warszawa 2008, s. 27-28.

${ }_{3}$ Za: tamże, s. 25.

${ }^{4}$ K. Błeszyńska, Stygmatyzacja, [w:] Encyklopedia pedagogiczna XXI wieku, red. T. Pilch, Warszawa 2006, s. 1102.

${ }^{5}$ C. Stangor, C.S. Crandall, Zagrożenie i społeczna konstrukcja piętna, [w:] Społeczna psychologia piętna, s. 75 . 
one wypadkową interaktywnych czynników sytuacyjnych i właściwości podmiotowych człowieka ${ }^{6}$. Funkcjonowanie jednostki w sytuacji możliwej stygmatyzacji jest zależne w znacznej mierze od zasobów psychospołecznych i umiejętności ich wykorzystania ${ }^{7}$. Nie każdy człowiek doświadczający skutków posiadanego piętna poddaje się jego znaczeniu, odrzucając tym samym przypisywaną etykietę. Nierzadko zdarza się też sytuacja odwrotna, w której on sam uruchamia mechanizmy właściwe dla procesu stygmatyzacji, nawet wbrew opinii czy reakcji społecznej. Biorąc pod uwage powyższe, spotykamy w literaturze określenie: „zagrożeni społeczną stygmatyzacją” w stosunku do grup uznawanych zazwyczaj w literaturze przedmiotu i opinii społecznej za stygmatyzowane. Wynika to z uznania, że nie można mieć pewności, czy proces stygmatyzacji zaistnieje w przypadku każdego członka grup uznanych powszechnie za piętnowane.

Można zatem wysunąć wniosek, że sam proces stygmatyzacji nie jest oczywisty i klarowny do określenia. Nie dziwi zatem fakt, że samo pojęcie stygmatu społecznego również stanowi wyzwanie dla badaczy tego zjawiska. Warto zatem przyjrzeć się bliżej temu zagadnieniu.

W literaturze przedmiotu termin "stygmat społeczny” jest stosowany zamiennie z pojęciem „piętno społeczne”. Zdaniem E. Czykwin ${ }^{8}$ te dwa terminy (stygmat - piętno) należy rozumieć bliskoznacznie, lecz nie synonimicznie. Piętnowanie podkreśla intencjonalność zjawiska i nie nasuwa skojarzeń ze stereotypem, podczas gdy stygmatyzacja ma charakter przede wszystkim nieintencjonalny, procesualny i interakcyjny. W rozumieniu procesu stygmatyzacji większy akcent jest położony na społeczną widownię, która stanowi podstawowy czynnik warunkujący zaistnienie zjawiska. Jednakże, znaczenie obu terminów podkreśla konieczność wystąpienia dwóch stron interakcyjnych - piętnowanego (stygmatyzowanego) i piętnującego (stygmatyzującego) oraz negatywny charakter omawianego procesu.

Są również przeciwne stanowiska odnoszące się do stosowania pojęcia "stygmat/stygmatyzacja”, dla których terminy te za bardzo skupiają uwagę na samych właściwościach osoby piętnowanej, a za mało na społecznych mechanizmach warunkujących wykluczenie 9 . Warto dodać, że Słownik języka polskiego ${ }^{10}$, czy też Słownik wyrazów obcych $i$ zwrotów obcojęzycznych ${ }^{11}$ te dwie

${ }^{6}$ A. Wilczyńska, Uwarunkowania radzenia sobie młodzieży w sytuacjach zagrożenia wykluczeniem spotecznym, Katowice 2013, s. 17.

7 I. Niewiadomska, Zasoby psychospołeczne czynnikiem warunkujacym pozytywna adaptacje człowieka, [w:] Skazani na wykluczenie!? red. M. Kalinowski, I. Niewiadomska, Lublin 2010, s. 20-22.

${ }^{8}$ E. Czykwin, Stygmat społeczny, Warszawa 2008, s. 22.

9 A. Tal, Is it Time to Retire the Term Stigma? Stigma Research and Action, 2012, (2).

${ }_{10}$ M. Szymczak, Stownik jezzyka polskiego PWN, Warszawa 1995, s. 336.

${ }^{11}$ W. Kopaliński, Stownik wyrazów obcych i zwrotów obcojęzycznych, Warszawa 1997. 
kategorie pojęciowe traktuje synonimicznie, a nie bliskoznacznie. Ich synonimiczność potwierdza również Encyklopedia pedagogiczna XXI wieku ${ }^{12}$.

Wydaje się zatem, że różnice pomiędzy tymi pojęciami są subtelne, bardziej intuicyjne, dlatego uzasadnione jest stosowanie tych terminów zamiennie - $\mathrm{w}$ ślad za innymi badaczami poruszanego zagadnienia - ale tylko w kontekście społecznym i relacyjnym (terminy zamiennie stosowane m.in. przez: E. Goffman (2007), P. Świtaj (2008), T.F. Heatherton, R.E. Kleck, M.R. Hebl, J.G. Hull, (2008), M. Świątkiewicz-Mośny (2010) i in.).

Odnosząc się do początków - pierwsze doniesienia dotyczące omawianych kwestii znane są już ze starożytności. Piętnem nazywano wtedy znamię wypalone na skórze niewolnika. Należy jednak podkreślić, że w czasach greckich nie miało ono negatywnych konotacji. Dopiero w starożytnym Rzymie znak ten związany był ze wstydem i degradacją społeczną ${ }^{13}$. Od tego czasu termin ten nabrał nowych znaczeń, jednak istota pozostała taka sama. Przyjmuje się, że „osoby stygmatyzowane to takie, które posiadają społeczny atrybut głęboko je dyskredytujący i które są postrzegane jako niepełnowartościowe $\mathrm{z}$ tego właśnie powodu"14.

\section{Konsekwencje relacyjne właściwości stygmatu}

Jak już zostało wspomniane, znacząca w przebiegu spotkania osoby doświadczającej skutków piętna z podmiotem postrzegającym jest widoczność posiadanego stygmatu. Opierając się na tym kryterium, E. Goffman ${ }^{15}$ wyróżnił dwie kategorie opisowe. Człowiek może posiadać właściwości:

1) zdyskredytowane (widoczne) - dotyczą one sytuacji, w których cechy oceniane potocznie jako "gorsze" są od razu widoczne bądź jednostka zakłada, że otoczenie wie o ich istnieniu (np. widoczna niepełnosprawność, otyłość);

2) dyskredytujące (niewidoczne) - stygmat jest niewidoczny w sytuacji powierzchownych relacji interpersonalnych. Jednostka zakłada, że otoczenie nie wie o jego istnieniu (np. homoseksualizm, analfabetyzm).

Widoczność i możliwość ukrycia piętna ma bardzo istotny wpływ na kształtowanie się relacji mieszanych, ponieważ istnieją odmienne problemy wynikające ze wzajemnego spotkania, a także rozwijane są inne strategie radzenia sobie z innością. Każda taka sytuacja wyróżnia się specyfiką problemów towarzyszących człowiekowi w jego codziennym funkcjonowaniu.

${ }^{12}$ K. Błeszyńska, Stygmatyzacja, s. 1102.

${ }^{13}$ A. Dijker, W. Koomen, Stygmatyzacja, tolerancja i naprawa. Integracyjna analiza psychologiczna reakcji na dewiacje, Białystok 2009, s. 41.

${ }^{14}$ E. Goffman, za: E. Czykwin, Stygmat społeczny, s. 16.

15 E. Goffman, Piętno. Rozważania o zranionej tożsamości, Gdańsk 2007, s. 34. 
W przypadku widoczności piętna pojawiają się kwestie autoprezentacji, adekwatnego odczytywania reakcji i oczekiwań otoczenia, a także dostosowania do społecznej widowni własnych zachowań. Występuje nieograniczony wpływ dyskredytujący na obraz własnej osoby i jej relacje z innymi ludźmi ${ }^{16}$. Zgodnie z ekologiczną teorią spostrzegania społecznego, ludzie są wrażliwi na wygląd zewnętrzny innych. Informacje dostarczane przez ich widoczne cechy często zostają uogólnione ${ }^{17}$. Na przykład: smukła sylwetka, schludny ubiór mogą oznaczać umiejętność samokontroli, natomiast otyłość - okazać się przedmiotem piętnowania ${ }^{18}$. Oczekiwania społeczeństwa wobec osoby ze stygmatem widocznym znacznie ograniczają dialog i kontakty społeczne. Relacje stają się pobieżne, a ich członkowie dążą do szybkiego ich zakończenia ${ }^{19}$.

Badania naukowe potwierdzają również istotne znaczenie pierwszych wrażeń związanych z określoną osobą. Jeden z eksperymentów psychologicznych w tym zakresie przeprowadził S. Asch ${ }^{20}$. Uczestnikom eksperymentu przeczytał opis fikcyjnej osoby, składający się z krótkiej listy przymiotników i prosił, by podali swoje wrażenia na jej temat. Jednej grupie badanych odczytano najpierw cechy pozytywne, a po nich negatywne. Drugiej grupie przedstawiono je natomiast w kolejności odwrotnej. Wyniki eksperymentu wskazywały, że w każdej grupie pierwsze wrażenie ukształtowało się na podstawie słowa, które przeczytano jako pierwsze. W związku z tym, choć obydwie grupy słyszały te same określenia, to jednak słowa usłyszane jako pierwsze najsilniej przyczyniły się do ukształtowania ostatecznego obrazu osoby opisywanej. W późniejszych badaniach potwierdzono zaobserwowaną zależność ${ }^{21}$.

Zmienną, która często bywa wymieniana jako odgrywająca znaczną rolę, jest spostrzegany stopień podobieństwa pomiędzy osobą oceniającą a ocenianą. Ludzie zwykle uważają za bardziej atrakcyjne osoby reprezentujące wartości czy postawy podobne do ich własnych ${ }^{22}$. Z pewnością, dla osób o widocznym piętnie ten mechanizm psychologiczny jest niezmiernie istotny. W sytuacjach braku możliwości ukrycia cechy stygmatyzującej, zarówno u osób piętnowanych, jak i piętnujących, pojawia się zakłopotanie w kontakcie. Podmiot postrzegający napotyka liczne problemy w interakcji, bo chociaż w trakcie socjali-

\footnotetext{
${ }^{16}$ K. Szewetowska, Stygmatyzacja społeczna, Edukacja i Dialog, 2009, (4), s. 57.

17 Za: F. Wojciechowski, Pedagogika specjalna wobec problemu mniejszościowych grup społecznie marginalizowanych, [w:] Pedagogika specjalna - aktualne osiagnięcia i wyzwania, red. T. Żółkowska, Szczecin 2005, s. 23.

${ }^{18} \mathrm{G}$. Green, The end of stigma. Changes in the social experience of long-term illness, USA-Canada 2009, s. 35.

${ }^{19}$ K. Szewetowska, Stygmatyzacja społeczna, s. 57.

20 Za: C. Sutton, Psychologia dla pracowników socjalnych, Gdańsk 2004, s. 63.

${ }^{21}$ Tamże, s. 63.

22 Tamże, s. 63-64.
} 
zacji nabył umiejętność wchodzenia w relację z drugim człowiekiem, to jednak w przypadku zakłócenia tej relacji nie wie jak postępować. Odmienność interakcji powoduje często zażenowanie i nieśmiałość. Dodatkowym problemem jest dobór odpowiednich kategorii opisu osoby ze stygmatem ${ }^{23}$.

Zatem, w relacji mieszanej jej uczestnicy konfrontują się z przyczynami i skutkami piętna. W takich okolicznościach osoba piętnowana może doświadczać: niepewności co do tego, w jaki sposób podmiot postrzegający określi ją i przyjmie, że nie podlega zwykłemu schematowi interpretacji codziennych zdarzeń. Na przykład: osoba ta ma świadomość, że nawet drobne osiągnięcia mogą zostać uznane za przejaw jej nadzwyczajnych zdolności; poczucie, że jej obecność wśród osób postrzegających naraża ją na naruszenie jej prywatności (np. wpatrywanie się w nią zaciekawionych „innością" dzieci); rodzi się także potrzeba ucieczki i unikania sytuacji problemowych. Często występuje również ostra reakcja defensywna w kontaktach społecznych ${ }^{24}$.

Przyjmuje się, że jedną z głównych możliwości nosiciela piętna widocznego jest praca nad tym, by wśród osób „normalnych” zachowywać się tak, jakby odmienność była w rzeczywistości nieistotna i niezauważona ${ }^{25}$. W tym kontekście warto bliżej przeanalizować sytuację społeczną wywołaną niepełnosprawnością. Wskazano, że nie ma grupy równie otwartej na ideę większego uczestnictwa w głównym nurcie społecznym niż osoby z niepełnosprawnościami, dla których współudział w ogólnodostępnym życiu jest istotnym komponentem skutecznej rehabilitacji ${ }^{26}$. Jednakże, w spotkaniu z człowiekiem, którego cechy zewnętrznej prezentacji odbiegają od szeroko rozumianej normy, rodzą się zazwyczaj silne emocje. Ukierunkowują one sposób postrzegania osób odmiennych przez społeczeństwo, a towarzyszące im pobudzenie stanowi mocny impuls do podjęcia określonego działania. Na przykład: obiekty wzbudzające lęk prowokują do ich unikania lub uciecz$\mathrm{ki}^{27}$. Dlatego, w kłopotliwych momentach wywołanych niepełnosprawnością można obserwować sprzeczne zachowania werbalne i niewerbalne pełnosprawnych członków interakcji. Powszechnie uważa się, że osobom z niepełnosprawnościami winna jest życzliwość, empatia i współczucie ${ }^{28}$. W związku

${ }^{23}$ E. Czykwin, Wstęp, [w:] „Gorsi inni” - badania, red. E. Czykwin, M. Rusaczyk, Białystok 2008, s. 197.

${ }^{24}$ Więcej: E. Goffman, Piętno, s. 45-50.

${ }^{25}$ Tamże, s. 77.

${ }^{26}$ F. Riessman, D. Carroll, Nowa definicja samopomocy. Polityka i praktyka, Warszawa 2000, s. $22-23$.

27 M. Lachowicz-Tabaczek, Emocje umystu: rola potocznych koncepcji świata i natury ludzkiej w regulacji percepcji zachowań, [w:] Psychologia poznania społecznego, red. M. Kossowska, M. Kofta, Warszawa 2009, s. 247.

${ }^{28}$ J. Hebl, R. Kleck, Społeczne konsekwencje niepetnosprawności fizycznej, [w:] Społeczna psychologia piętna, s. 391. 
z tym zachowania werbalne są na ogół bardzo pozytywne, jednak w postawie niewerbalnej można zaobserwować: unikanie, sztywność ruchów, większy dystans podczas interakcji, jak również zmniejszoną spontaniczność ${ }^{29}$. Można więc umiejętnie prezentować pozory akceptacji (tego wymaga kontekst socjalizacyjny), jednak kłopotliwe momenty w relacjach tego typu mogą nadal pozostawać nacechowane lękiem i zakłopotaniem ${ }^{30}$. Jawna postawa jest zatem związana z przemyślanymi zachowaniami, natomiast ukryta - ze spontaniczną, niekontrolowaną reakcją na daną sytuację ${ }^{31}$. Co więcej, w obliczu odmienności mamy częściej do czynienia z postawą rezygnacji i uległości, niż jakiejkolwiek ingerencji - ta wymaga bowiem wiedzy na temat napotkanej inności, a także umiejętności przewidzenia konsekwencji z niej wynikających ${ }^{32}$.

W takich sytuacjach pozostaje możliwość dążenia do normalizacji stosunków społecznych. F. Davis ${ }^{33}$ wyróżnia trzy etapy na drodze do jej zaistnienia. Pierwszy zatrzymuje się na fikcyjnej akceptacji. Tu obserwujemy zachowania wynikające z uprzejmości, dobrego wychowania, pewnego rodzaju kurtuazji. Następnie - w tak zwanej fazie przejścia - podmiot postrzegający zaczyna postrzegać osobę odmienną przez pryzmat również innych jej cech, nie tylko tych widocznie odmiennych. Następnie dochodzi do instytucjonalizacji znormalizowanych interakcji, gdzie inność uznaje się za fragment osobowości człowieka, która wprawdzie istnieje, ale nie przeszkadza w normalnych $\mathrm{z}$ nim kontaktach. Proces ten jest doskonale identyfikowany przez osoby doświadczone stygmatem. Osoby z niepełnosprawnościami twierdzą, że są w stanie rozpoznać bez trudu partnerów interakcji, którzy postrzegają ich jako potencjalnie bezradnych i zależnych. Można podać przykład osób niewidomych, które od razu dostrzegają ów szczególny sposób traktowania ich przez widzących - zwracają się oni do nich wolno i wyraźnie ${ }^{34}$.

Uważa się, że ze względu na liczne korzyści płynące z tego, że jest się uznanym za osobę „normalną”, prawie wszyscy mający możliwość pomijania swojego piętna, zrobią to z pewnością przy jakiejś okazji ${ }^{35}$. Z taką sytuacją spotykamy się w przypadku piętna możliwego do ukrycia. Wówczas w relacjach interpersonalnych chodzi bardziej o umiejętne kierowanie kłopotliwą

29 N. Maliszewski, M. Czyżewska, I. Krejtz, Postawy jawne a postawy ukryte jako wyznaczniki poznania i zachowania społecznego, [w:] Psychologia poznania społecznego, red. M. Kossowska, M. Kofta, Warszawa 2009, s. 185.

30 M. Hebl, J. Tickle, T. Heatherton, Kłopotliwe momenty w interakcjach między jednostkami niestygmatyzowanymi a stygmatyzowanymi, [w:] Społeczna psychologia piętna, s. 265.

31 N. Maliszewski, M. Czyżewska, I. Krejtz, Postawy jawne a postawy ukryte, s. 185.

32 A. Perzanowski, Odmieńcy. Antropologiczne studium dewiacji, Warszawa 2009, s. 197.

33 Za: A. Siemaszko, Granice tolerancji. O teoriach zachowań dewiacyjnych, Warszawa 1993, s. 362 .

34 E. Czykwin, Stygmat społeczny, Warszawa 2008, s. 114.

35 E. Goffman, Piętno, s. 113. 
informacją. Wraz z potrzebą ukrywania stygmatu rodzi się konieczność przewidywania możliwych reakcji otoczenia, analiza sytuacji potencjalnie zagrażających jego demaskacją, a także próba ich unikania oraz tworzenie i rozwijanie strategii maskujących ${ }^{36}$. Zachowanie sekretu staje się troską znacznie absorbującą, a próby utrzymania tajemnicy aktywizują zbiór procesów poznawczych, które z kolei mogą prowadzić do obsesyjnego myślenia o posiadanym stygmacie. Kiedy człowiek z możliwym do ukrycia piętnem aktywnie usiłuje je zataić, to sekret ten może stać się bardziej dostępny właśnie wówczas, kiedy podejmowane jest wzmożone staranie, aby o nim nie myśleć. Jest to proces na tyle dotkliwy, że być może największym pragnieniem, jakie mogłaby mieć osoba z możliwym do ukryciu piętnem, byłoby nawet nie jego brak, lecz zniknięcie myśli o nim ${ }^{37}$. Odmienność jest więc tutaj pewnego rodzaju konfiguracją bezradności i strachu ${ }^{38}$.

Sytuacja warunkująca konieczność utrzymania sekretu sprawia, że człowiek zmaga się nie tylko z faktem posiadania danej cechy nieakceptowanej, ale też boryka się $\mathrm{z}$ własnym, obsesyjnym zaabsorbowaniem piętnem. To zaabsorbowanie wpływa zazwyczaj pośrednio na całościowy sposób jego funkcjonowania społecznego. Ponadto, badania psychologiczne wykazują, że nawet wówczas, kiedy osoby te uważają podejmowane próby stłumienia myśli o swych piętnach za wystarczająco skuteczne, myśli te nadal wpływają na ich zachowania i oceny ${ }^{39}$. Wysiłki te są jednak podejmowane często, ponieważ utrzymywanie $\mathrm{w}$ tajemnicy swojej dyskredytującej cechy często umożliwia włączenie się w główny nurt życia społecznego. Należy jednak zauważyć, że piętno możliwe do ukrycia wpływa na długotrwałe relacje społeczne silniej niż na krótkoterminowe interakcje $\mathrm{z}$ otoczeniem. Tłumaczy się to przez fakt, że trudniej zachować sekret $w$ relacjach głębszych, dlatego osoby te mogą wybierać powierzchowne kontakty, w których ukrywanie piętna jest stosunkowo latwe ${ }^{40}$.

Pozostaje pytanie, jak radzić sobie w sytuacjach dnia codziennego z doświadczanymi skutkami piętna. Literatura wskazuje szereg strategii - użytecznych w zależności od charakteru stygmatu i kontekstu sytuacyjnego - które są obserwowane w postawach osób stygmatyzowanych. Warto wymienić kilka podstawowych, czyli osoby takie mogą ${ }^{41}$.

${ }^{36}$ K. Błeszyńska, Stygmatyzacja, s. 1103.

${ }^{37}$ L. Smart, D. Wagner, Ukryte koszty ukrytego piętna, [w:] Społeczna psychologia piętna, s. 208.

38 A. Perzanowski, Odmieńcy, s. 197.

${ }^{39}$ L. Smart, D. Wagner, Ukryte koszty ukrytego piętna, s. 208-209.

40 Tamże, s. 209.

41 Za: E. Goffman, Piętno, s. 40-41; M. Świątkiewicz-Mośny, Tożsamość napiętnowana. Socjologiczne studium mechanizmów stygmatyzacji i autostygmatyzacji na przykładzie kobiet z zespotem Turnera, Kraków 2010, s. 31-32; L. Smart, D. Wagner, Ukryte koszty ukrytego piętna, s. 217-218. 
1. Podjąć bezpośrednią korektę tego, co uchodzi za obiektywną podstawę jej upośledzenia - na przykład operacja plastyczna. Niestety, częstym skutkiem jest jedynie zmiana tożsamości z kogoś posiadającego określoną widoczną cechę dyskredytującą w kogoś, kto ma za sobą jedynie jej korektę.

2. Podejmować wysiłki $w$ celu opanowania tych dziedzin aktywności, które uchodzą za niedostępne dla kogoś z określonym piętnem (np. wspinaczki górskie podejmowane przez osoby z niepełnosprawnością ruchową).

3. Zerwać z tak zwaną rzeczywistością i obstawać przy własnej interpretacji swojej tożsamości społecznej.

4. Czerpać ze swojego piętna zyski, usprawiedliwiając wszelkie niepowodzenia w innych obszarach swojego życia.

5. Zatrzeć symbol piętna (np. osoby uzależnione od narkotyków kłują się w mniej widocznych miejscach niż żyła na ręce).

6. Dzielić świat na dwie części - wyróżniamy dużą grupę, która niczego nie wie o stygmacie i małą, która wie o stygmacie wszystko.

7. Uprzedzić wszystkich o piętnie - stygmat dyskredytujący zmienia się w stygmat o właściwościach zdyskredytowanych. Zmienia zatem swoją sytuację. Nie musi zarządzać kłopotliwą informacją, ale musi poradzić sobie $\mathrm{z}$ niepewną sytuacją społeczną.

8. W przypadku piętna niewidocznego można wypracować mechanizm automatyzacji tłumienia. Z upływem czasu ukrywanie sekretu jest skuteczniejsze. Na przykład, jednostka z przeszłością kryminalną po wielu latach utrzymywania jej w sekrecie może stwierdzić, że ukrywanie to staje się łatwiejsze.

9. Kierować sytuacją w taki sposób, aby chronić się przed koniecznością zachowywania tajemnicy oraz stosowania tłumienia, poprzez unikanie okoliczności, w których trzeba to piętno ukrywać.

10. Przedefiniować piętno, czyli zinterpretować je w taki sposób, że już nie jest ono stygmatyzujące lub przynajmniej nie jest już istotne dla kwestii odnoszących się do tożsamości danej osoby. Wtedy też można o nim zapomnieć, ponieważ aktywne dochowywanie tajemnicy przestaje być potrzebne.

11. Osoba doświadczająca swojej stygmatyzującej inności może dokonywać projekcji tej odmienności na osoby ze swojego otoczenia, stwierdzając, że to oni są fizycznie lub moralnie odmienni. Ten sposób patrzenia na świat może być jednym z nieświadomych produktów ubocznych ukrywania piętna. Taka sytuacja często jest łączona z motywacją do negowania istnienia tego piętna w sobie. Można też konstruować świat, w którym ich piętna są postrzegane jako bardziej rozpowszechnione niż to ma miejsce $w$ rzeczywistości. Taki sposób myślenia może tymczasowo łagodzić stres.

Warto dodać, że osoby z widocznym piętnem zazwyczaj bardziej koncentrują się na otoczeniu i na fizycznych cechach partnerów interakcji, a mniej 
na treści rozmów. Osoby z ukrytym piętnem natomiast odwrotnie - zwykle skupiają swoją uwagę na treści rozmowy, co ważne, przyjmując często punkt widzenia swoich partnerów. Ta subtelna różnica odzwierciedla zmiany percepcyjne, zależne od widoczności głównych wyznaczników posiadanego stygmatu. Mówiąc ogólnie: pierwsza grupa musi koncentrować się na już „zepsutej interakcji” i pozostawać czujnym na oznaki prawdziwych postaw i uczuć rozmówcy. Osoby z piętnem niewidocznym muszą raczej kontrolować rozmowę i zwracać uwagę na to, co się mówi, a także próbować odczytywać myśli partnera interakcji tak, aby pokierować rozmową w sposób umożliwiający dalsze ukrywanie piętna ${ }^{42}$.

Duży wpływ na przebieg procesu stygmatyzacji ma także źródło stygmatu - jego kontrolowalność i brak kontroli nad jego przyczyną. Innymi słowy - możliwość przypisania komuś winy za „niższy” status społeczny lub nie. W przy padku, w którym doszło do naruszenia zasad współżycia społecznego, reakcję społeczną możemy zakwalifikować jako ostracyzm punitywny, który jest motywowany potrzebą ukarania tej osoby za to, co zrobiła ${ }^{43}$. Na przykład: inaczej będzie kształtowała się opinia społeczna o osobie niewidomej, a inaczej o osobie opuszczającej zakład karny (w obu przypadkach piętno jest bardzo dotkliwe, choć inaczej oceniane). Niechęć otoczenia albo odrzucenie osoby, która opuściła zakład karny, spowodowane jest lękiem, poczuciem, że źródłem piętna tej osoby jest sama osoba napiętnowana ${ }^{44}$. Proces jej stygmatyzacji rozpoczyna się już $\mathrm{w}$ fazie trwania dochodzenia i aresztu, kiedy daje się podejrzanemu do zrozumienia, że należy (bądź może przynależy) do przestępczej mniejszości społecznej. Postępowanie organów wymiaru sprawiedliwości zakończone wyrokiem skazującym oznacza pierwszy etap instytucjonalnego naznaczenia. Utrata wolności jest dla wielu osób skazanych dowodem ich moralnego odrzucenia i potępienia przez wolne społeczeństwo. Następny etap stygmatyzacji odbywa się już w instytucji zamkniętej, która ma właściwe jej prawa i środki dalszego etykietowania tych, którzy znaleźli się w jej obrębie. Przez cały okres uwięzienia oraz po wyjściu na wolność przypomina się człowiekowi, że utracił status normalnego obywatela i został zaliczony do kategorii przestępców ${ }^{45}$.

Jest to sytuacja, w której niezwykle trudno pozbyć się stygmatu. Starożytni Grecy oznaczali swoich niewolników znamieniem, aby nie mogli oni ukryć swojej tożsamości społecznej przed innymi ludźmi. Współcześnie można spotkać

${ }^{42}$ L. Smart, D. Wagner, Ukryte koszty ukrytego piętna, s. 212.

${ }^{43}$ K. Williams, L. Wheeler, J. Harvey, Podróż w głąb umystu społecznego osoby stosującej ostracyzm, [w:] Umyst społeczny. Poznawcze i motywacyjne aspekty zachowań interpersonalnych, red. J. Forgas, K. Williams, L. Wheeler, Gdańsk 2005, s. 302.

${ }_{44}$ C. Stangor, C.S. Crandall, Zagrożenie i spoteczna konstrukcja piętna, s. 87.

${ }^{45}$ M. Ciosek, Psychologia sądowa i penitencjarna, Warszawa 2001, s. 216. 
się z podobną praktyką $\mathrm{w}$ podkulturze więziennej. Osadzeni tatuują symbole dobrowolnie bądź są przymuszani do takiej praktyki przez współwięźniów, jednak nie znak tatuażu na ciele, ale znak na tożsamości jest obecnie problemem tych ludzi. Tatuaż więzienny można zlikwidować, wiele osób nie zna jego znaczenia. Współcześnie ma zupełnie inny wydźwięk niż w Grecji. Rys „osadzonego" pozostaje zatem we wnętrzu człowieka. Wielu naukowców ${ }^{46}$ uważa, że niemożliwa jest reintegracja byłych więźniów, ponieważ przed wyrokiem nie byli oni dobrze zintegrowani ze społeczeństwem, a zatem idea ponownej integracji to iluzja. Jeżeli $\mathrm{w}$ społecznej świadomości panuje takie przeświadczenie, to osoby $\mathrm{z}$ takim piętnem nigdy nie będą $\mathrm{w}$ pełni $\mathrm{w}$ głównym nurcie społecznym ${ }^{47}$. Co więcej, osoby po wyjściu na wolność mają często problemy ze znalezieniem pracy. $\mathrm{W}$ momencie, $\mathrm{w}$ którym pracodawca dowiaduje się o uprzedniej karalności, kwestia ewentualnego zatrudnienia staje się bardziej dyskusyjna. Ponadto, najbliższa społeczność lokalna traktuje osobę jako naznaczoną wieloma negatywnymi cechami. Poczucie bycia "gorszym” i braku szans na normalne życie powoduje wracanie do dewiacyjnego pełnienia ról ${ }^{48}$. Można powiedzieć, że społeczne oczekiwania wobec osób stygmatyzowanych są najczęściej nietrafne i mają zabarwienie negatywne. Nietrafność percepcji ma swoje źródło w stereotypach, braku wiedzy i wynika z negatywnych porównań $\mathrm{z}$ innymi, co może prowadzić do wniosku, iż osoba odmienna jest postrzegana jako obca i niezrozumiała, a takie zakwalifikowanie stanowi symbol odczytywany w społeczeństwie jako niebezpieczeństwo ${ }^{49}$.

Sytuacja osób z niepełnosprawnościami, którym nie sposób przypisać winy za ich cechy utrudniające funkcjonowanie społeczne, warunkuje w sposób skuteczny pozytywne postawy jawne. Niemniej jednak stwierdza się, że „niepełnosprawność jest tradycyjnie wymieniana - obok przestępczości, degradacji ekonomicznej czy kulturowej - jako najczęstsza przyczyna marginalizacji społecznej" ${ }^{50}$. Jest to związane głównie z faktem widocznej odmienności, ale także utrudnieniami organicznymi, które naruszają równowagę pomiędzy tym, do czego człowiek dąży, pragnie, czy potrzebuje a możliwościami osiągnięcia wytyczonych celów ${ }^{51}$.

${ }^{46}$ L. Shantz, J. Kilty, S. Figorn, Echoes of imprisonment: Women's Experiences of "Succesful (re) integration", Canadian Journal of Law and Society, 2009, (1), s. 87.

47 Tamże; A. Brzezińska, Struktura obrazu wtasnej osoby i jego wptyw na zachowanie, Kwartalnik Pedagogiczny, 1973, (3).

${ }^{48}$ Por: B. Pikor, S. Antończak, Piętno pobytu w zakładzie karnym. Pobrano z lokalizacji http:/ / www.wszia.edu.pl/images/old/prace_kol_zeszyt4/17.pdf [dostęp: 20.11.2014].

49 E. Czykwin, Stygmat spoteczny, s. 110.

${ }^{50}$ Za: B. Kosek-Nita, D. Raś, Kontakty z ludźmi "innymi” jako problem wychowania, opieki i resocjalizacji, Katowice 2007, s. 116.

51 Por: Z. Ratajczyk, Oblicza ludzkiej zaradności, [w:] Człowiek w sytuacji zagrożenia. Kryzysy, katastrofy, kataklizmy, red. K. Popiołek, Poznań 2001, s. 15. 
Poruszając kwestię związaną z kontrolowalnością i widocznością piętna, konieczne wydaje się wyjaśnienie kwestii „samospełniającego się proroctwa”. Na przykład: przekonanie, że osoby z niepełnosprawnością są zależne, może sprawiać, że zachowujemy się wobec nich w sposób szczególnie troskliwy, a to paradoksalnie wywołuje $\mathrm{u}$ nich zachowania zależne. Im większa pewność wystąpienia określonych zachowań (własnych lub cudzych), tym większe jest prawdopodobieństwo pojawienia się zjawiska samospełniającego się proroctwa ${ }^{52}$. Podobnie powrót osób uprzednio karanych pozbawieniem wolności do działalności kryminalnej potwierdza społeczną klasyfikację tych osób w kategoriach zagrożenia i konieczności podejmowania wobec nich dalszych, surowych kroków karnych ${ }^{53}$. Zjawisko to daje się tłumaczyć również poprzez teorię samopotwierdzenia, gdzie przyjmuje się, że ludzie mają potrzebę potwierdzenia swojego pojęcia ja, niezależnie czy jest ono pozytywne czy negatywne, co w określonych sytuacjach może pozostawać w sprzeczności z potrzebą podtrzymania dobrego mniemania o sobie ${ }^{54}$.

Historia osoby ze stygmatem jest zawsze dramatem rozgrywającym się w czasie. W sytuacji kiedy następuje stopniowy, progresywny proces zmian, na przykład osoby, które wyszły z uzależnienia muszą być przygotowane na to, że stygmat będzie im ciążył na długo po opuszczeniu ośrodka terapeutycznego - może nawet do końca ich życia ${ }^{55}$. Pewne cechy odpowiadające stereotypowi "narkomana" będą mu przypisywane pomimo poradzenia sobie z problemem. Dzieje się tak dlatego, gdyż osoba uzależniona jest traktowana jako niegodna zaufania, osoba ze słabą wolą, osoba niebezpieczna. Jest też na ogół obwiniana za swój status społeczny. Istnieje przekonanie, że przed uzależnieniem od narkotyków można się uchronić poprzez na przykład niewchodzenie w zagrażające kontakty społeczne z osobami rozprowadzającymi substancje psychoaktywne. Niemniej jednak fakt podjęcia leczenia może być postrzegany jako forma kompensacji odpowiedzialności. Co więcej, jeżeli przedstawimy osobę uzależnioną od narkotyków jako uzależnioną z powodu wcześniejszego leczenia medycznego za pomocą substancji uzależniających, społeczeństwo ujawnia więcej zrozumienia i mniej gniewu, aniżeli kiedy informacji tej nie było ${ }^{56}$.

Kwestia przypisania winy za obecny status społeczny jest kluczowa dla społecznego percypowania danej odmienności. Co więcej, przeżywanie poczucia winy jest $\mathrm{w}$ pewnych sytuacjach niemal wymagane $\mathrm{z}$ punktu widzenia oczekiwań społecznych. Taka sytuacja dotyczy szczególnie osób, które

\footnotetext{
52 Tamże, s. 111.

${ }^{53}$ B. Pikor, S. Antończak, Piętno pobytu w zakładzie karnym.

${ }^{54}$ E. Aronson, T. Wilson, R. Akert, Psychologia społeczna, Poznań 2006, s. 454.

${ }^{55}$ E. Czykwin, Stygmat społeczny, s. 112.

56 A. Dijker, W. Koomen, Stygmatyzacja, tolerancja i naprawa, s. 85-86.
} 
popełniły przestępstwa, łamiąc tym samym zasadę wzajemności. W takich okolicznościach wymaga się, żeby osoba, która dopuściła się takiego czynu, okazała poczucie winy. Wtedy zachodzi możliwość wywołania u osoby poszkodowanej, a także osób postronnych uczucia sympatii, przebaczenia, jak również zmniejszenia dotkliwości ewentualnej kary. Dla osób obserwujących oznaki przeżywania tej emocji są dowodem, że nie jest on "całkowicie zły” oraz że istnieje nadzieja na jego naprawę i ponowne włącznie do społeczności $^{57}$. Badania J. Bieleckiej-Prus potwierdzają, że strategiczna (niejednokrotnie udawana) prezentacja poczucia winy podczas procesu sądowego pojawia się bardzo często. Zabiegi takie potwierdzają wypowiedzi respondentów zgromadzone przez autorkę tych badań, którzy w taki sposób opisywali sytuację na rozprawie sądowej: "udawałem, aby nie było gorzej, ale nie czutem poczucia winy”; "pokazuję skruchę, robię smutna minę, przepraszam i mówię, że się to nie powtórzy"; "próbowatem się popłakać, ale nie umiem. Spuściłem wzrok i nic nie mówiłem”; "w sadzie zawsze trzeba pokazywać skruchę, żeby sąd wiedziat, że naprawdę żałuję. Po co? "Aby mieć mniejszy wyrok"58.

Wszystkie te zabiegi stosowane są $\mathrm{w}$ celu podtrzymania pozytywnego obrazu siebie oraz zmniejszenia dystansu społecznego, jaki tworzy się w relacjach mieszanych. Istnieje kilka hipotez potwierdzonych badaniami naukowymi, które w jakimś stopniu tłumaczą predykatory jego zwiększenia lub zmniejszenia. Uznano, że stopień dystansu uwarunkowany jest głównie czynnikami ekonomicznymi, społecznymi i kulturowymi ${ }^{59}$. Dodatkowo zaznacza się, że na ogół wyższy dystans wobec pewnych (etykietowanych) grup przejawiają osoby starsze. Płeć natomiast nie stanowi czynnika różnicującego. Wysoki stopień dystansu jest również słabo związany z niskim wykształceniem, natomiast różnice kulturowe $\mathrm{w}$ istotny sposób warunkują jego nasilenie. Liczne badania potwierdzają także, że kontakt (osobiste doświadczenie relacji $\mathrm{z}$ osobą potencjalnie stygmatyzowaną) znacznie zmniejsza stopień społecznego dystansu, natomiast doniesienia badaczy nie są jednoznaczne co do wpływu wiedzy na temat określonych grup na stopień przejawianego dystansu. Warto również zwrócić szczególną uwagę w kontekście omawianych tu zależności na fakt, że jeżeli stygmat jest związany ze słabością charakteru (a więc w potocznym myśleniu z możliwością przypisania winy za doświadczane trudności), dystans ten jest na ogół wyższy ${ }^{60}$.

${ }^{57}$ J. Bielecka-Prus, Poczucie winy jako emocja społeczna. Analiza wybranych nurtów badawczych, Przegląd Socjologii Jakościowej, 2013, IX(2), s. 118.

58 Tamże, s. 104-123

${ }^{59} \mathrm{~W}$. Bottero, K. Prandy, Social interaction distance and stratification, British Journal of Sociology, 2003, (2), s. 194.

${ }^{60}$ A. Jorm, E. Oh, Desire for social distance from people with mental disorders: a review, Australian and New Zealand Journal of Psychiatry, 2009, 43, s. 184. 
Badania nad poziomem społecznego dystansu potwierdzają również, że jeżeli postrzega się pewne grupy $w$ kategoriach zagrożenia, to czynnik ten znacznie potęguje jego natężenie ${ }^{61}$. Jako czynniki mogące pomóc obniżyć stopień dystansu podaje się optymalizację równowagi pomiędzy członkami grup o nierównym statusie, wzmocnienie ich współpracy dla osiągnięcia wspólnie wytyczonych celów oraz stworzenie przestrzeni dla bliskich relacji pomiędzy członkami grup. Przyjmuje się, że te podstawowe czynniki mogą obniżyć zakłopotanie $\mathrm{w}$ relacjach, lęk i niepewność ${ }^{2}$.

Szczególna uwaga badaczy w psychologii społecznej skoncentrowana jest wokół „hipotezy kontaktu”, która głosi, że kontakt pomiędzy członkami zwaśnionych grup prowadzi do obniżenia poziomu wzajemnych uprzedzeń oraz do poprawy ogólnych relacji międzygrupowych. Jest to jedna z najstarszych koncepcji psychologii, niemniej jednak do dziś wzbudza duże zainteresowanie $^{63}$. Uznano jednak, że kontakt między grupami prowadzi do ograniczania uprzedzeń tylko wówczas, kiedy zaspokojone są pewne funkcjonalne wymogi relacji pomiędzy grupami. Na przykład, już M. Sherif podkreślał rolę współpracy pomiędzy grupami i współzależności, natomiast G. Allport wymienił cztery sytuacyjne wymogi skutecznego kontaktu: równy status grup; codzienna współpraca; wspólne cele; wsparcie władz i prawa ${ }^{64}$. Współcześnie mówi się o potrzebie kontaktu spersonalizowanego, który mógłby służyć zmniejszeniu społecznego dystansu pomiędzy grupą "swoją" a grupą "obcą". Grupa „obca" jest postrzegana jako stosunkowo mało zróżnicowana, zwarta i odrębna w przeciwieństwie do grupy „własnej”. Natomiast, jeżeli dostrzega się różnice w kategorii grupy własnej i obcej, to niektórzy członkowie obu grup postrzegani są jako nietypowi. Wraz ze wzrostem postrzeganego zróżnicowania granice grup wydają się stawać coraz bardziej nietrwałe i przepuszczalne. W końcu przynależność grupowa staje się zupełnie nieistotna. Uważa się, że tylko spersonalizowana interakcja, która oznacza postrzeganie siebie i partnera interakcji w kategoriach jego osobistych atrybutów, a nie przynależności do określonej kategorii społecznej, skutecznie niweluje dystans społeczny ${ }^{65}$.

Chodzi więc o pewne pokonanie kategoryzacji, która jest podstawą dla uruchomienia procesu stereotypizacji. Postrzeganie jednostki, która ze wzglę-

${ }^{61}$ Więcej: D. Marie, B. Miles, Social distance and perceived dengerousness across four diagnostic categories of mental disorder, Australian and New Zealand Journal of Psychiatry, 2008, (42), s. 126-132.

${ }^{62}$ F. Anagnastopoulos, A. Hantzi, Familiarity with and Social Distance from People with Mental Illness: Testing the Mediating Effects of Prejudiced Attitudes, Journal of Community and Applied Social Psychology, 2011, 21, s. 452.

${ }^{63}$ M. Bilewicz, Kiedy kontakt ostabia uprzedzenia? Kategoryzacje społeczne i temporalne jako warunki skutecznego kontaktu międzygrupowego, Psychologia Społeczna, 2006, (2), s. 63.

${ }^{64}$ Tamże.

${ }^{65}$ Tamże. 
du na posiadaną cechę zaliczona zostanie do jednej kategorii grupy społecznej potocznie ocenianej pejoratywnie, sprawi, że przypiszemy jej wszystkie pozostałe cechy tej kategorii, bez względu na jej rzeczywiste właściwości ${ }^{66}$. Obraz świata jednostki ulega przecież ciągłej reinterpretacji i dokonuje się $\mathrm{w}$ procesie interakcji pomiędzy jednostką a społecznym, kulturowym i materialnym środowiskiem - i to właśnie w nim jednostka weryfikuje rzeczywistość dostępnych jej ujęć kategorialnych oraz uzyskuje pewnego rodzaju niezależność $\mathrm{w}$ tej relacji ${ }^{67}$. Spostrzeżenie różnic pomiędzy członkami grup obcych - ale przede wszystkim dostrzeganie ich kapitału - stanowią silny czynnik dla osłabienia procesu stygmatyzacji, a sam proces ustalenia znaczeń w kontekście społecznym ma kluczowe znaczenie dla codziennej sytuacji życiowej człowieka zagrożonego jego skutkami.

\section{Zakończenie}

Celem artykułu było zaprezentowanie właściwości stygmatu w kontekście sytuacji życiowej człowieka zagrożonego stygmatyzacją. Na podstawie zaprezentowanych treści można wnioskować, że w percypowaniu odmienności i uruchomieniu dotkliwego procesu stygmatyzacji kluczowe pozostają właściwości posiadanego piętna. Zwłaszcza jego widoczność i kontrolowalność (możliwość przy pisania winy za doświadczane trudności przez społeczną widownię, a także postrzeganie stopnia zawinienia przez sam podmiot postrzegany). Zaprezentowana tutaj literatura przedmiotu nie pozostawia wątpliwości, że czynniki te w znacznym stopniu warunkują procesy wzajemnych relacji pomiędzy grupami. Nie ma natomiast jednoznacznych danych co do wpływu wiedzy na temat grup zagrożonych stygmatyzacją na stopień dystansu. Niemniej jednak przyjmuje się, że jest to również istotny czynnik mogący obniżyć poziom uprzedzeń wobec konkretnych grup czy osób ${ }^{68}$.

\section{BIBLIOGRAFIA}

Anagnastopoulos F., Hantzi A., Familiarity with and Social Distance from People with Mental Illness: Testing the Mediating Effects of Prejudiced Attitudes, Journal of Community and Applied Social Psychology, 2011, 21.

${ }^{66}$ Z. Janiszewska-Nieścioruk, T. Żółkowska, Paradygmat obcego, [w:] Relacje i doświadczenia społeczne osób z niepetnosprawnością, red. C. Kosakowski, A. Krause, M. Wójcik, Torun-Olsztyn 2009, s. 28.

67 Por. B. Ostafińska-Molik, Postrzeganie siebie i własnego zachowania w kontekście zaburzeń adaptacyjnych młodzieży, Kraków 2014, s. 62.

68 A. Jorm, E. Oh, Desire for social distance from, s. 184. 
Aronson E., Wilson T., Akert R., Psychologia społeczna, Zysk i S-ka Wydawnictwo, Poznań 2006.

Bielecka-Prus J., Poczucie winy jako emocja społeczna. Analiza wybranych nurtów badawczych, Przegląd Socjologii Jakościowej, 2013, IX(2).

Bilewicz M., Kiedy kontakt osłabia uprzedzenia? Kategoryzacje społeczne i temporalne jako warunki skutecznego kontaktu międzygrupowego, Psychologia Społeczna, 2006, (2).

Błeszyńska K., Stygmatyzacja, [w:] Encyklopedia pedagogiczna XXI wieku, red. T. Pilch, Wydawnictwo Akademickie Żak, Warszawa 2006.

Bottero W., Prandy K., Social interaction distance and stratification, British Journal of Sociology, 2003, (2).

Brzezińska A., Struktura obrazu własnej osoby i jego wptyw na zachowanie, Kwartalnik Pedagogiczny, 1973, (3).

Chrzanowska I., Funkcjonowanie dzieci upośledzonych umysłowo w stopniu lekkim w szkole podstawowej, Wydawnictwo Uniwersytetu Łódzkiego, Łódź 2003.

Ciosek M., Psychologia sądowa i penitencjarna, Stella Marius, Warszawa 2001.

Czapiński J., Przesłanki ustosunkowań wobec innych ludzi, [w:] Psychologia spostrzegania społecznego, red. W.M. Lewicka, Książka i Wiedza, Warszawa 1985.

Czykwin E., Stygmat społeczny, Wydawnictwo Naukowe PWN, Warszawa 2008.

Czykwin E., Wstęp, [w:] „Gorsi inni” - badania, red. E. Czykwin, M. Rusaczyk, Trans Humana, Białystok 2008.

Davidio J.F., Major B., Crocer J., Piętno: wprowadzenie i zarys ogólny, [w:] Społeczna psychologia piętna, red. T. Heatherton, R. Kleck, M. Hebl, J. Hull, Wydawnictwo Naukowe PWN, Warszawa 2008.

Dijker A., Koomen W., Stygmatyzacja, tolerancja i naprawa. Integracyjna analiza psychologiczna reakcji na dewiacje, Fundacja „Tolerancja”, Białystok 2009.

Goffman E., Piętno. Rozważania o zranionej tożsamości, Gdańskie Wydawnictwo Psychologiczne, Gdańsk 2007.

Green G., The end of stigma. Changes in the social experience of long-term illness, Routladge, USA-Canada 2009.

Hebl J., Kleck R., Społeczne konsekwencje niepetnosprawności fizycznej, [w:] Społeczna psychologia piętna, red. T. Heatherton, R. Kleck, M. Hebl, J. Hull, Wydawnictwo Naukowe PWN, Warszawa 2008.

Hebl M., Tickle J., Heatherton T., Kłopotliwe momenty w interakcjach między jednostkami niestygmatyzowanymi a stygmatyzowanymi, [w:] Społeczna psychologia piętna, red. T. Heatherton, R. Kleck, M. Hebl, J. Hull, Wydawnictwo Naukowe PWN, Warszawa 2008.

Janiszewska-Nieścioruk Z., Żółkowska T., Paradygmat obcego, [w:] Relacje i doświadczenia społeczne osób z niepetnosprawnościa, red. C. Kosakowski, A. Krause, M. Wójcik, Wydawnictwo Edukacyjne Akapit, Torun-Olsztyn 2009.

Jorm A., Oh E., Desire for social distance from people with mental disorders: a review, Australian and New Zealand Journal of Psychiatry, 2009, 43.

Kosek-Nita B., Raś D., Kontakty z ludźmi „innymi” jako problem wychowania, opieki i resocjalizacji, Wydawnictwo Uniwersytetu Śląskiego, Katowice 2007.

Lachowicz-Tabaczek M., Emocje umystu: rola potocznych koncepcji świata i natury ludzkiej w regulacji percepcji zachowań, [w:] Psychologia poznania społecznego, red. M. Kossowska, M. Kofta, Wydawnictwo Naukowe PWN, Warszawa 2009.

Maliszewski N., Czyżewska M., Krejtz I., Postawy jawne a postawy ukryte jako wyznaczniki poznania i zachowania społecznego, [w:] Psychologia poznania społecznego, red. M. Kossowska, M. Kofta, Wydawnictwo Naukowe PWN, Warszawa 2009. 
Marie D., Miles B., Social distance and perceived dengerousness across four diagnostic categories of mental disorder, Australian and New Zealand Journal of Psychiatry, 2008, (42).

Nan X., Social Distance, Framing, and Judgment: A Construal Level Perspective, Human Communication Research, 2007, (33).

Niewiadomska I., Zasoby psychospołeczne czynnikiem warunkujacym pozytywna adaptację człowieka, [w:] Skazani na wykluczenie!? red. M. Kalinowski, I. Niewiadomska, Wydawnictwo KUL, Lublin 2010.

Ostafińska-Molik B., Postrzeganie siebie i własnego zachowania w kontekście zaburzeń adaptacyjnych młodzieży, Wydawnictwo Uniwersytetu Jagiellońskiego, Kraków 2014.

Perzanowski A., Odmieńcy. Antropologiczne studium dewiacji, Wydawnictwo DiG, Warszawa 2009.

Pikor B., Antończak S., Piętno pobytu w zakładzie karnym. Pobrano z lokalizacji http:/ / www. wszia.edu.pl/images/old/prace_kol_zeszyt4/17.pdf [dostęp: 20.11.2014].

Riessman F., Carroll D., Nowa definicja samopomocy. Polityka i praktyka, Państwowa Agencja Rozwiązywania Problemów Alkoholowych, Warszawa 2000.

Shantz L., Kilty J., Figorn S., Echoes of imprisonment: Women's Experiences of "Succesful (re) integration", Canadian Journal of Law and Society, 2009, (1).

Siemaszko A., Granice tolerancji. O teoriach zachowań dewiacyjnych, PWN, Warszawa 1993.

Smart L., Wagner D., Ukryte koszty ukrytego piętna, [w:] Społeczna psychologia piętna, red. T. Heatherton, R. Kleck, M. Hebl, J. Hull, Wydawnictwo Naukowe PWN, Warszawa 2008.

Stangor C., Crandall C.S., Zagrożenie i społeczna konstrukcja piętna, [w:] Społeczna psychologia piętna, red. T. Heatherton, R. Kleck, M. Hebl, J. Hull, Wydawnictwo Naukowe PWN, Warszawa 2008.

Sutton C., Psychologia dla pracowników socjalnych, Gdańskie Wydawnictwo Psychologiczne, Gdańsk 2004.

Szczęsna H., Percepcja, [w:] Encyklopedia pedagogiczna XXI wieku, red. T. Pilch, Wydawnictwo Akademickie Żak, Warszawa 2006.

Szewetowska K., Stygmatyzacja społeczna, Edukacja i Dialog, 2009, (4).

Tal A., Is it Time to Retire the Term Stigma? Stigma Research and Action, 2012, (2).

Wilczyńska A., Uwarunkowania radzenia sobie młodzieży w sytuacjach zagrożenia wykluczeniem społecznym, Wydawnictwo Uniwersytetu Śląskiego, Katowice 2013.

Williams K., Wheeler L., Harvey J., Podróż w głąb umystu społecznego osoby stosującej ostracyzm, [w:] Umyst społeczny. Poznawcze i motywacyjne aspekty zachowań interpersonalnych, red. J. Forgas, K. Williams, L. Wheeler, Gdańskie Wydawnictwo Psychologiczne, Gdańsk 2005.

Wojciechowski F., Pedagogika specjalna wobec problemu mniejszościowych grup społecznie marginalizowanych, [w:] Pedagogika specjalna - aktualne osiagnięcia i wyzwania, red. T. Żółkowska, Oficyna in Plus Wydawnictwo Pomorza Zachodniego, Szczecin 2005. 